\title{
Sustainable Development and Digitalization: The Unusual COVID-19 Crisis Requires Original Solutions ${ }^{1}$
}

\author{
T. Lanshina, V. Barinova, A. Kondratyev, M. Romantsov
}

Tatyana Lanshina - PhD in Economics, Senior Researcher at the Center for Economic Modeling of Energy and Ecology of the Russian Academy of National Economy and Public Administration under the President of the Russian Federation (RANEPA); Manager of the international network for finding solutions in the field of sustainable development SDSN in Russia; bldg. 1, 82 Prospekt Vernadskogo, Moscow, 119571, Russian Federation; E-mail: lanshina@ranepa.ru

Vera Barinova - Ph.D., Deputy Director of the Center for Economic Modeling of Energy and Ecology of the Russian Academy of National Economy and Public Administration under the President of the Russian Federation (RANEPA); manager of the international network for finding solutions in the field of sustainable development SDSN in Russia; bldg. 1, 82 Prospekt Vernadskogo, Moscow, 119571, Russian Federation; E-mail: barinova@ranepa.ru

Andrey Kondratyev - second-year master's student at the National Research University "MPEI", Institute of Electrical Engineering and Electrification, Department of Power Supply for Industrial Enterprises and Electrotechnology; 14 Krasnokazarmennaya Ulitsa, Moscow, 111250, Russian Federation; second year student in Management, Department of Sustainable Development Economics, Moscow Witte University; 12 (1) 2nd Kozhukhovskiy proezd, Moscow, 115432, Russian Federation; E-mail: kdg040598@gmail.com

Mikhail Romantsov - second year student in Management, Department of Sustainable Development Economics, Moscow Witte University; 12 (1) 2nd Kozhukhovskiy proezd, Moscow, 115432, Russian Federation

\begin{abstract}
This article provides a content analysis of over 20 policy proposals for coping with the COVID-19 crisis that have been published by influential international organizations, governments, corporations, academics and civil society groups. The current situation, the role of digitalization during the crisis, and the composition of anti-crisis measures already taken by the world's largest economies are investigated, and long-term measures are proposed aimed at restoring the global economy and moving toward more equitable and sustainable development.

The authors identify a significant green component in public policy proposals published since the pandemic began and note that many proposals relate to equity and inclusiveness in development and meeting the needs of individuals. The authors further identify key areas of sustainable development that require action in the near future and which can create new opportunities for economic development: renewable energy and clean transport, cyclical economy, digitalization and environmental protection. At the same time, it is noted that the transition to a green economy is of a long-term nature and may conflict with the need in the short term to support the economy in overcoming the crisis.

These priority areas for government action require attention within the framework of Russia's anti-crisis policy. Given the sharp drop in oil prices, the acceleration of digitalization and decarbonization, and the magnitude of the 2020 economic crisis, Russia needs to begin an accelerated transition to low-carbon energy, a cyclical economy and the restoration of its ecosystems with accelerated digitalization.
\end{abstract}

Key words: Sustainable Development Goals (SDGs); Agenda 2030; digitalization; COVID-19 pandemic; anti-crisis policy

${ }^{1}$ The editorial board received the article in August 2020. 
For citation: Lanshina T., Barinova V., Kondratyev A., Romantsov M. (2020) Sustainable Development and Digitalization: The Unusual COVID-19 Crisis Requires Original Solutions. International Organisations Research Journal, vol. 15, no 4, pp. 91-114 (in English). DOI: 10.17323/1996-7845-2020-04-05.

\section{Introduction}

The COVID-19 pandemic has significantly changed the lives of millions of people around the world as well as economic relations. It has led to temporary breaks in production, logistics and commercial processes. Many companies have temporarily transferred their employees to remote work and are starting to deliberate on remote employment in the longer term. In the first half of 2020, Internet usage intensity in the world increased by 50-70\% [Ramos, 2020]. Energy demand has dropped significantly. At the end of 2020, the International Energy Agency (IEA) expects a 5\% decrease in global electricity demand. Traditional electric power generation (using fossil fuels and nuclear energy) is declining, with only renewable energy generation showing growth [IEA, 2020a]. A sharp decline in mobility has reduced the demand for oil - according to the Organization of the Petroleum Exporting Countries (OPEC) forecasts, in 2020 the world may consume $10 \%$ less oil than in 2019 [Lawler, 2020].

These unprecedented changes will have dramatic economic consequences, and their magnitude has not yet been fully realized. In June 2020, the International Monetary Fund (IMF) expected the global economy to shrink by $4.9 \%$ in 2020 , which is $1.9 \%$ lower than the April forecast by same organization [IMF, 2020]. The June 2020 forecast of the World Bank predicts a 5.2\% decline in the global gross domestic product (GDP) in 2020 [World Bank, 2020]. The world has not experienced such a deep recession since the end of World War II.

All this raises questions about how to pursue future development. Shall we support mature industries and large corporations first or shall we emphasize small and medium enterprises? Shall we invest in large-scale infrastructure projects, many of which cause serious harm to the environment, or prioritize infrastructure projects with reduced environmental pollution and greenhouse gas emissions? Is it necessary to support traditional businesses or focus on creating conditions for innovations and new green sectors?

The concept of sustainable development has become the most important development paradigm in recent years. It was the basis of the United Nations (UN) General Assembly resolution "Transforming Our World: The 2030 Agenda for Sustainable Development" (Agenda 2030), adopted in 2015 by 193 UN member countries. The 2030 Agenda includes 17 interrelated sustainable development goals (SDGs) and 169 corresponding targets, which imply coherent development in three areas: economic growth, social justice and environmental protection. This document refers to all states, as well as to commercial and non-commercial organizations. It is assumed that national governments and regional administrations, as well as corporate management, universities and non-profit organizations, will voluntarily localize the SDGs, implement them and thus contribute to the implementation of the global Agenda 2030.

Despite the fact that the concept of sustainable development emerged almost half a century ago, there are still quite few solid scientific research papers on this topic. In foreign studies, authors predominantly investigate the relationships between various SDGs [Biggeri et al., 2019; Le Blanc, 2015; Zhou, Moinuddin, 2017] as well as the inclusion of the 2030 Agenda into national development strategies [Bickler, Morton, Menne, 2020; Sebestyén, Domokos, Abonyi, 2020]. In Russia, several works have been devoted to the adaptation and implementation of the SDGs [Ignatov et al., 2019; Lanshina et al., 2019]. Some investigate the situation in Russia 
[Bobylev, Solovyova, 2017; Sakharov, Kolmar, 2019] and the role of business in achieving the SDGs [Dunayev, Nagornov, 2017].

With the global COVID-19 pandemic crisis, sustainability issues are being reviewed. In particular, the clear need for digitalization and low-carbon development becomes increasingly obvious. Given this, the main objectives of this article are to analyze the anti-crisis policy proposals of influential international actors and to analyze the reflection of these proposals in the recovery programmes already approved by governments. These tasks are of particular relevance for Russia, since Russia lags significantly behind other countries in the localization and implementation of the SDGs and in the sphere of low-carbon development. Ignoring these aspects during the implementation of anti-crisis policies can increase this gap. The aim of this article is to develop recommendations for anti-crisis measures based on international experience.

This article draws on content analysis of the main global proposals to combat the consequences of the COVID-19 crisis and already approved anti-crisis programmes, as well as elements of comparative analysis.

\section{Digitalization and the Green Sector in Sustainable Development}

Among the many sectors of the modern economy, digital technologies and the green sector play a special role in sustainable development. It is rather difficult to give precise definitions for these actively developing sectors. According to the IMF, digitalization encompasses a wide range of new ways to apply information technologies to business models and products that are transforming economies and social connections. By "digital sector," the IMF means information and communication products and services, online platforms and the activities on these platforms (for example sharing economy) [IMF, 2018]. According to the UN Environmental Programme (UNEP), a green economy can improve well-being and social equity while significantly reducing environmental risks. In its simplest definition, the green economy is low-carbon, resource efficient and socially inclusive [UNEP, 2011]. Thus, the green sector can comprise energy efficient technologies, renewable energy sources, elements of a circular economy, sustainable agriculture, sustainable forest management and so on.

These two sectors are the basis of the most important economic transformations of our time: digitalization is the foundation of the fourth industrial revolution, and the green sector is a key element of the green industrial revolution. Moreover, they play an important integrating role between the three key areas of sustainable development. The digital economy reconciles economic and social development by making government services as well as public goods (education, health care) more accessible, making it easier to create new companies, jobs and added value. The green economy reconciles economic and environmental development, allowing economic growth while reducing environmental damage through the use of renewable energy technologies, sustainable agriculture, environmentally friendly materials and circular economy mechanisms.

Digital and green sectors are mutually important. Digital technologies make the green sector more efficient and reliable and are helping to save energy. In the future, digital energy systems will be able to identify which consumers need energy and deliver it at the right time and at the lowest costs. In their turn, data centres are already the largest energy consumers - they account for about $1 \%$ of total global electricity demand. Thus, energy efficiency and the ability to use renewable energy sources is becoming increasingly important for digital sector.

Progress in digital and green sectors is fundamentally reshaping economic activity and business-as-usual models and creating opportunities for balanced economic, social and environmental development consistent with the concept of sustainable development. Further, digitalization and green development affect almost every SDG, and their spread is possible with the implementation of each of the goals. 
Digitalization plays a special role in the SDGs' implementation. The 2030 Agenda is largely based on data governance. The document emphasizes the importance of the availability of "high quality, relevant and reliable data, disaggregated by income, gender, age, race, nationality, migration status, disability, geographic location and other characteristics that are relevant to national conditions." Such complex data system management is impossible without the use of modern digital technologies.

Moreover, digitalization expands opportunities to localize the SDGs. For example, the introduction of e-government with electronic transactions improves the quality of public services and their availability, as well as the interaction between the state and business and the overall efficiency of public administration. In many cases, this leads to a decrease in corruption and an increase in transparency and therefore contributes to the achievement of SDG 16 ("peace, justice and strong institutions") [ElMassah, Mohieldin, 2020]. According to T. Janowski [2016], e-government plays a key role in the implementation of the SDGs, and most of the 2030 Agenda targets require digitalization opportunities. It is noteworthy that, according to Janowski's findings, most European Union (EU) countries do not have the necessary digitalization competencies to implement the 2030 Agenda. This means that the global potential of the digital sector in sustainable development is far from being achieved.

The pandemic has caused a variety of experiments. It has changed the way of life of millions of people, their daily communications, working hours and migration patterns. Remote work has become a new normal. Online shopping has skyrocketed. Various services such as consultations, sports and education have moved to the online realm. Countries with developed digital sectors turned out to be more prepared for the pandemic's challenges and were able to transfer many economic activities online in a short time. Even if life returns to its usual format after the pandemic, these trends will not go unnoticed and will affect the further global development.

\section{Key Proposals for Anti-Crisis Policies}

A large number of reports and studies on the COVID-19 crisis aimed at developing anti-crisis policies predict dramatic consequences for the global economy, including a significant reduction in well-being for most of the global population. The world is facing the deepest economic crisis in its post-war history. Thus, according to the June report of the International Labour Organization (ILO), in the second quarter of 2020 alone, the number of working hours in the world decreased by $14 \%$, which is equivalent to the loss of 400 million jobs [ILO, 2020]. This means that the consequences of the crisis may be worse than the pandemic itself.

Many international organizations, corporations and representatives of government bodies suggest not only support for business but also adherence to international agreements related to the SDGs' implementation and climate action. A review of the anti-crisis proposals of the world's leading organizations from 15 March to 31 July 2020 shows that more than 20 proposals were collected in 4.5 months, which are presented below (Table 1). All significant proposals from reputable organizations or individuals were collected without taking into account whether they are related to digitalization, the green sector or sustainable development in general.

The Club of Rome urged world leaders not to respond to the current crisis with shortsighted decisions, which can increase emissions and have a negative impact on the environment in the long term. The letter also notes that anti-crisis measures should not focus on grants they should include strong economic incentives which could help companies and industries move to low-carbon circular business models. 


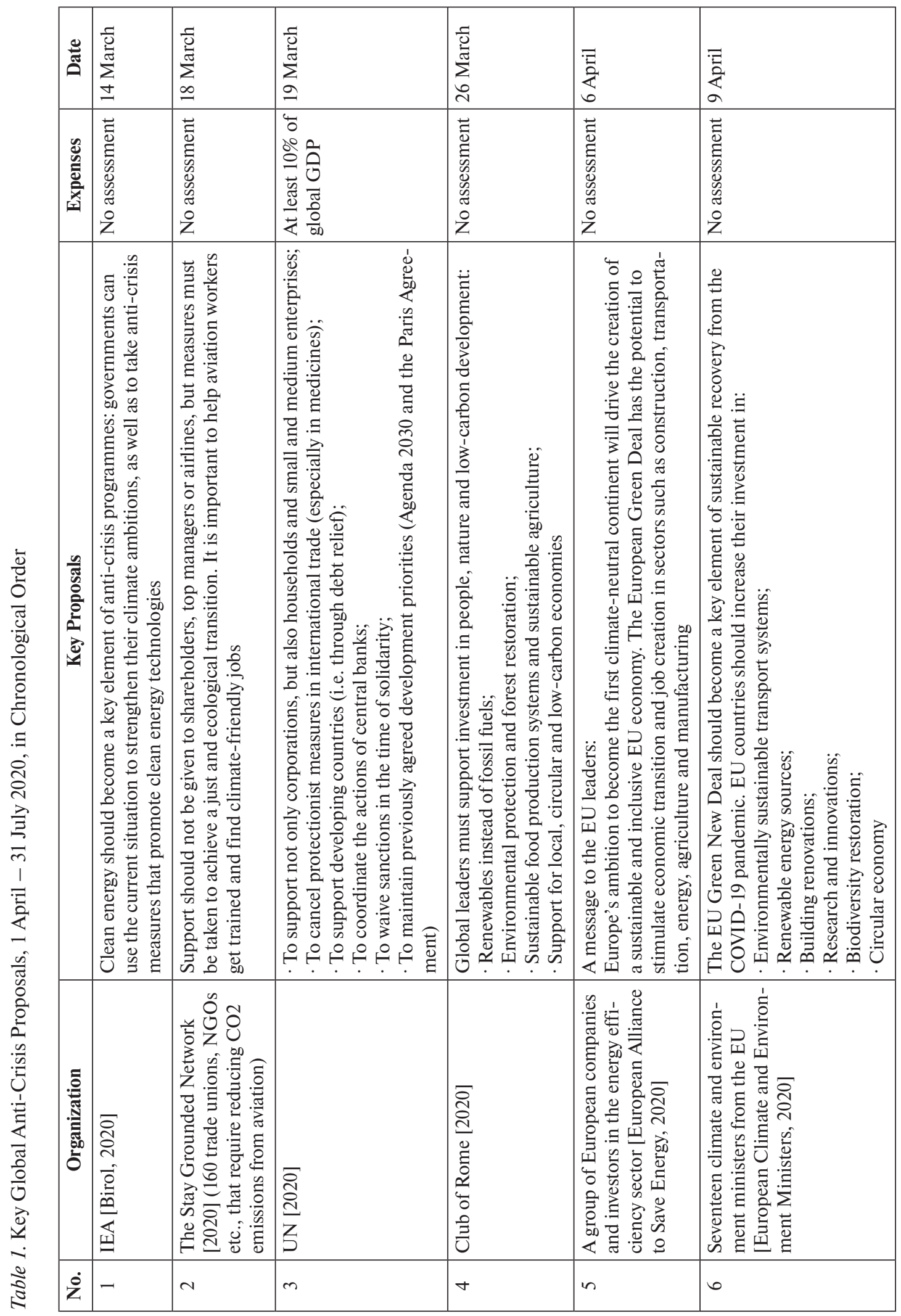




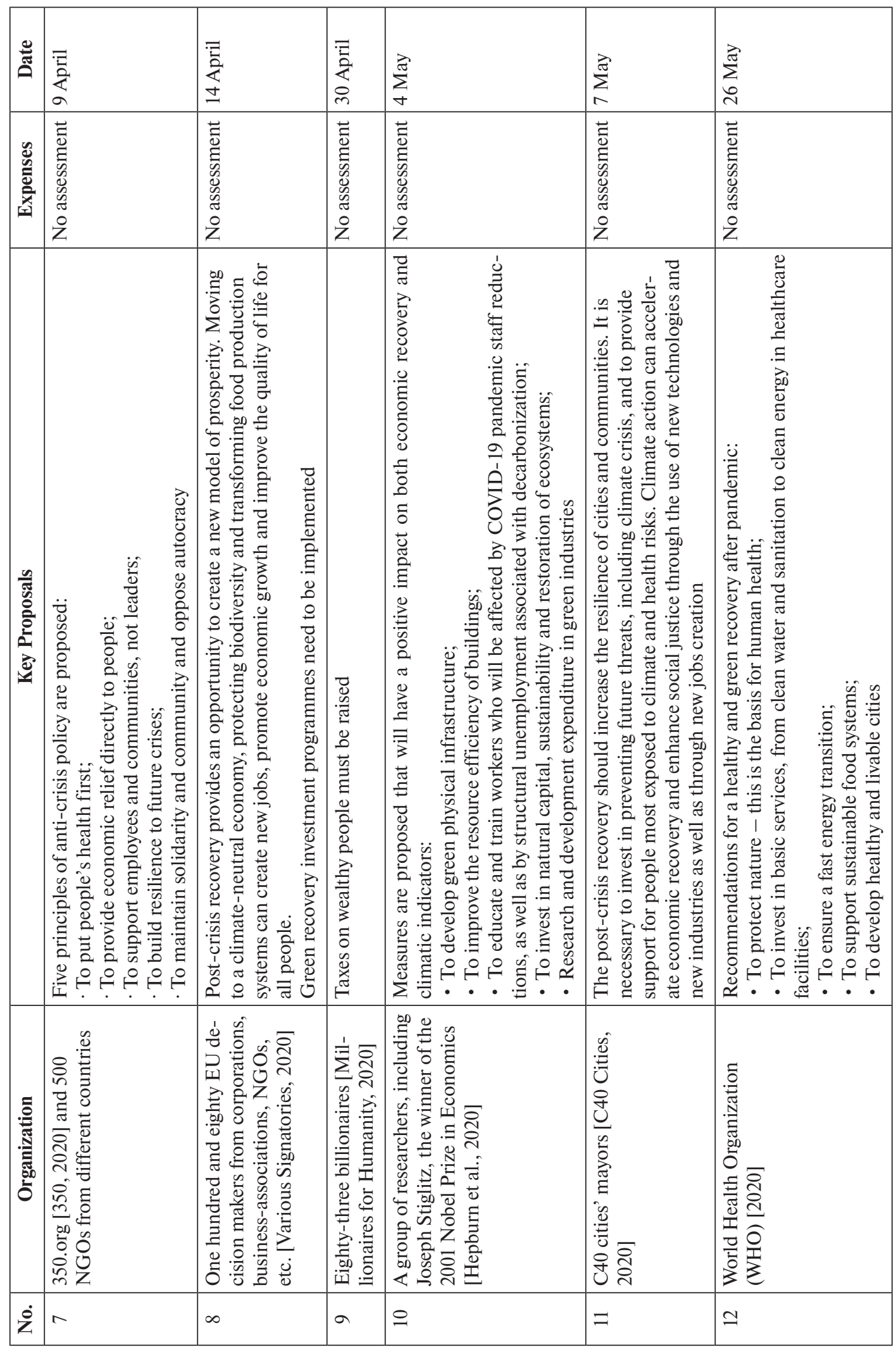




\begin{tabular}{|c|c|c|c|c|c|c|}
\hline 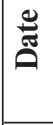 & 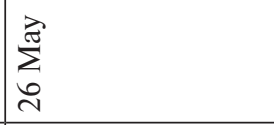 & $\stackrel{\Xi}{\Xi}$ & $\stackrel{\Xi}{\Xi}$ & \begin{tabular}{|l}
0 \\
$\Xi$ \\
in
\end{tabular} & $\stackrel{\Xi}{\Xi}$ & 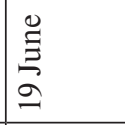 \\
\hline 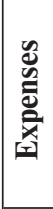 & 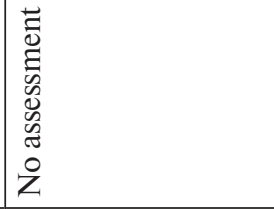 & 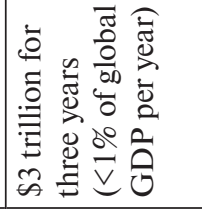 & 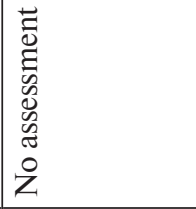 & 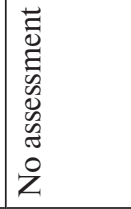 & 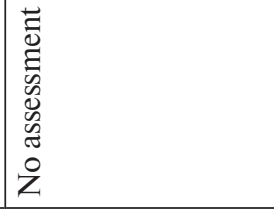 & 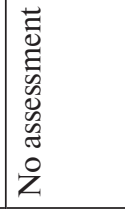 \\
\hline 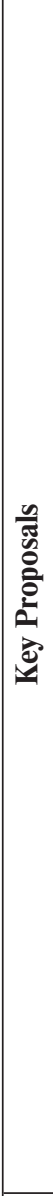 & 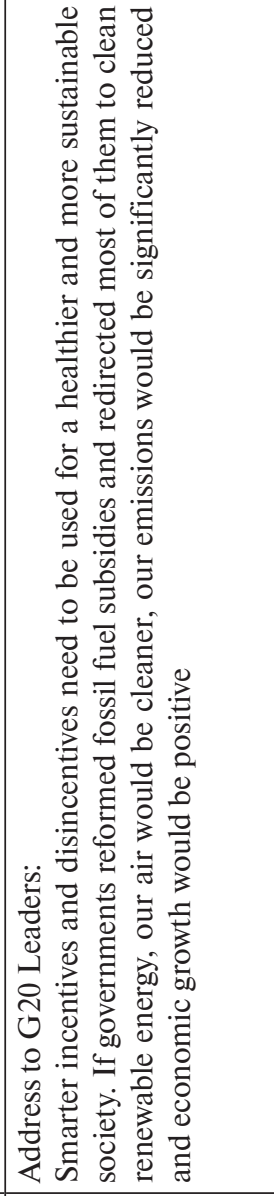 & 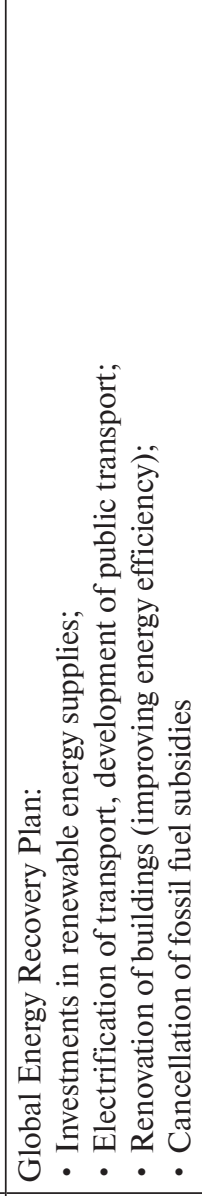 & 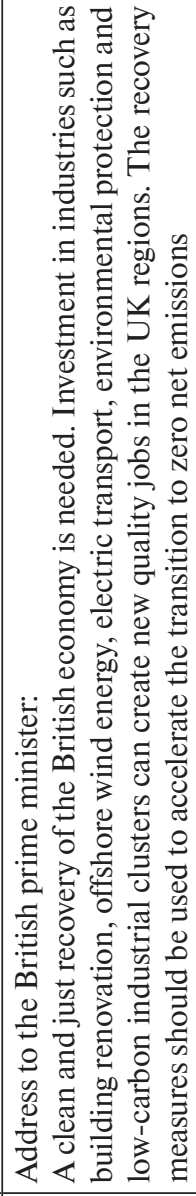 & 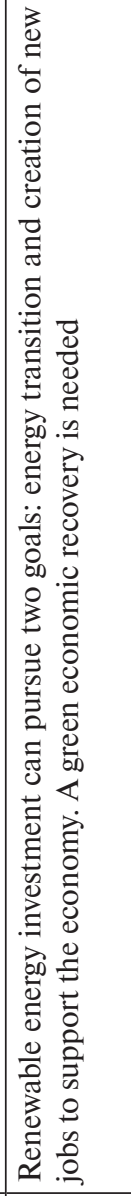 & 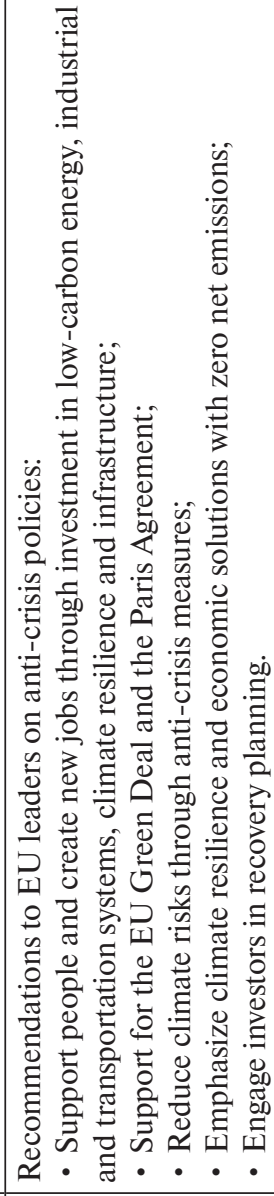 & 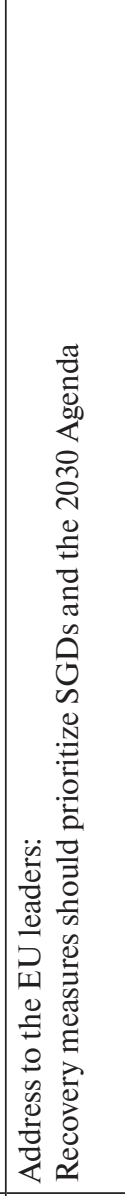 \\
\hline 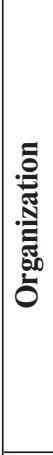 & 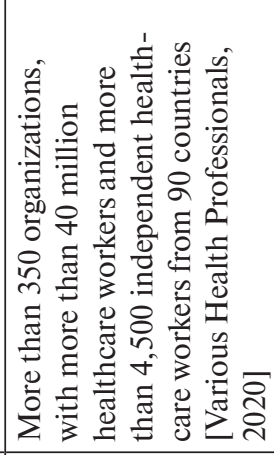 & 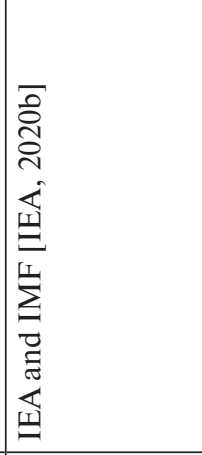 & 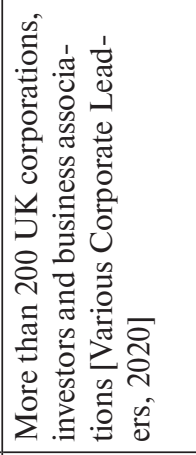 & 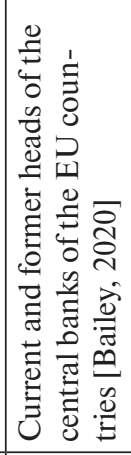 & 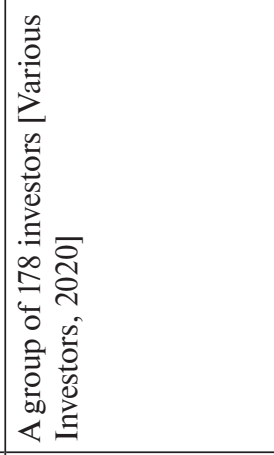 & 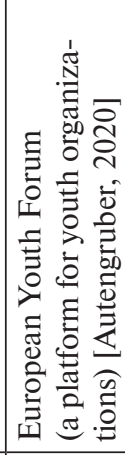 \\
\hline$\dot{z}$ & 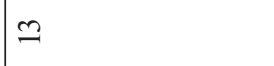 & \pm & $\because$ & 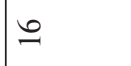 & $=$ & $\infty$ \\
\hline
\end{tabular}




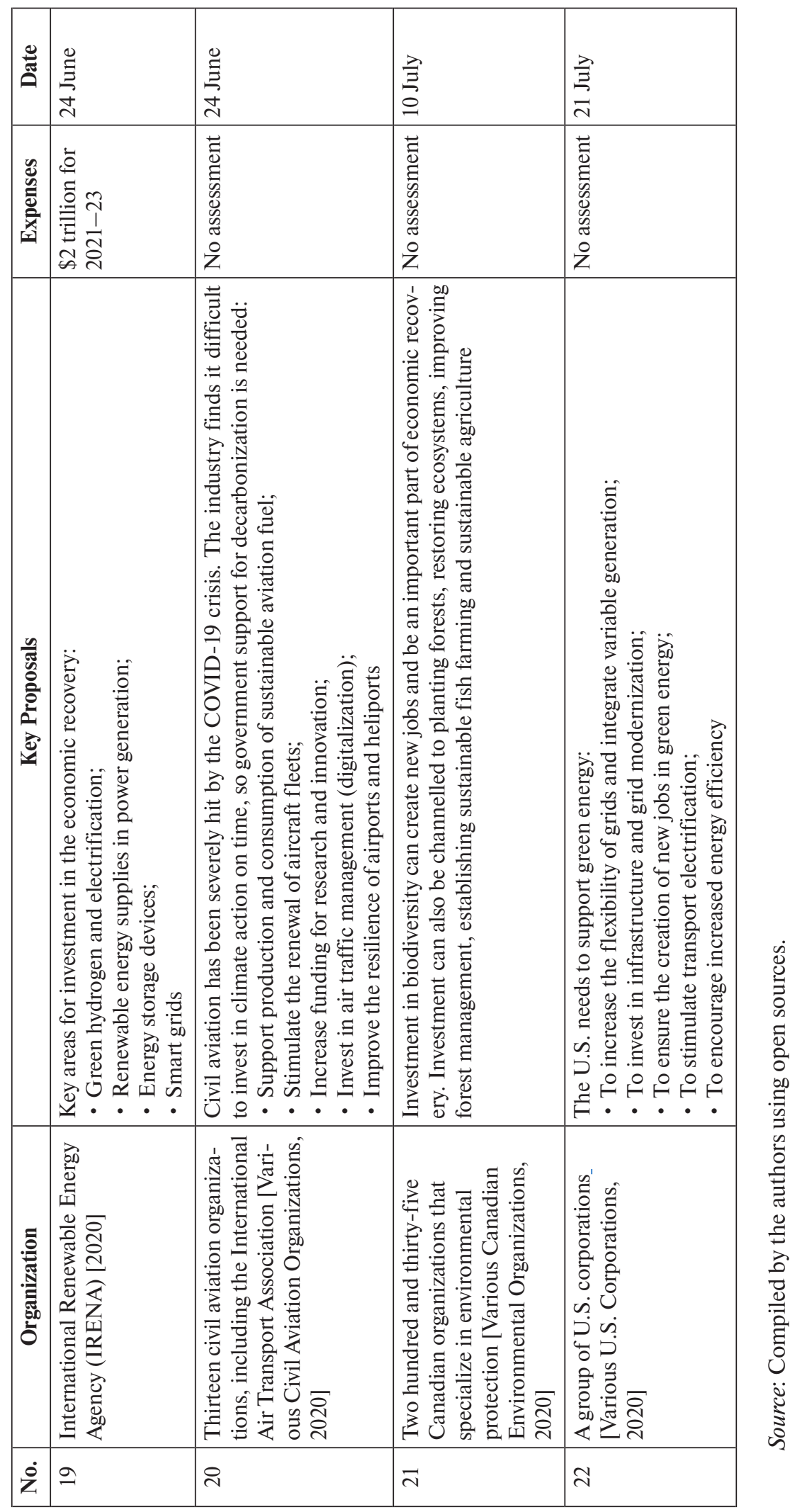


Some proposals are surprising for their content and the power of reasoning. On 21 July 2020, American companies and American branches of foreign and multinational corporations such as Nestle, Unilever, PepsiCo, McDonald's Corporation and others - the largest consumers of energy in the country - published a letter to the U.S. Congress asking it to support green energy (Table 1). Thus, corporations that employ millions of Americans and are not related to the energy sector see the way out of the healthcare crisis as being through investment in green energy. In their letter, they argue that money invested in clean energy creates about three times more jobs than money invested in fossil fuels, for every dollar spent. Similar jobs figures are contained in the proposal of the International Renewable Energy Agency (IRENA): each $\$ 1$ million investment creates three times more jobs in renewable energy than in traditional energy [IRENA, 2020].

This is not the only example of large businesses advocating a commitment to sustainable development and green sectors during the pandemic. Earlier, in April 2020, 68 German corporations - including representatives of a wide range of industries from financial services to the construction sector and heavy industry - published a letter urging the government to address the crisis by supporting green industries and taking action to implement the Paris Agreement. More than 200 UK corporations and a group of European companies and energy efficiency investors made similar calls.

Another surprising announcement was the appeal of 83 millionaires, including Abigail Disney, the great-granddaughter of the Walt Disney Company's co-founder, to increase taxes on the wealthiest citizens in order to raise funds to combat the consequences of the pandemic. Millionaires noted in their open letter that it is government taxation, not charity, that can contribute to solving the problem.

Another interesting proposal was prepared by 235 Canadian environmental organizations, which suggested that the crisis can be surmounted by investing in the conservation and restoration of biodiversity. These investments can create new jobs, including those in the regions, and improve the environmental and social situation.

It is important to mention the statement by medical personnel from 90 countries (Table 1). In May, more than 350 organizations representing more than 40 million healthcare workers and more than 4,500 individual healthcare professionals issued an open letter urging Group of 20 (G20) leaders to consult with their chief health officers and scientific advisers when developing anti-crisis incentives. They also argued that the impact of these measures on the health of the population in the long term should be assessed. In addition, the group of doctors called for the cancellation of fossil fuel subsidies and channelling the freed funds to renewable energy to reduce emissions and improve public health. On the same day, the World Health Organization made a similar statement.

The European aviation sector supports the European Commission's approach which combines economic recovery and transition toward sustainable development. At the same time, the need to support the aviation industry in the sphere of decarbonization and digitalization is noted, as the industry has been badly affected by the crisis. Stimulation of sustainable fuel production, funding for research and innovation in clean aviation, and introduction of new digital technologies at airports and for air navigation is required.

An important feature of anti-crisis proposals is the requirement to place individuals, communities and small and medium businesses at the centre of economic recovery programmes. Such proposals usually have come from the non-profit sector.

A paper by a group of renowned scholars including Joseph Stiglitz, 2001 Nobel laureate in economics and professor at Columbia University [Hepburn et al., 2020], had a major impact on current anti-crisis ideas. In order to identify incentive policies that are likely to produce good results in terms of both economic recovery and climate change mitigation, they conducted a 
survey of 231 representatives of central banks, ministries of finance and other experts from the G20 countries. This resulted in the identification of five areas in which investment should be made to combat the economic consequences of the COVID-19 crisis. These areas are listed in No. 10 in Table 1, of which four are directly related to the green economy.

As is clear from the above analysis, many proposals for anti-crisis policies contain calls for support of the development of renewable energy sources. At the same time, it is important to note the following: even if countries do not take any action to stimulate renewables, this sector will be one of the few that will demonstrate positive growth by the end of 2020. One of the documents reviewed - the Global Energy Recovery Plan, published by IEA and IMF in June 2020, contains the following global forecasts for the energy sector for 2020: oil demand will decrease by $8 \%$, gas demand by $4 \%$, coal demand by $8 \%$, the volume of nuclear electricity production will drop by $2.5 \%$, the demand for electricity will drop by $5 \%$ (in some regions by $10 \%$ ) and the volume of electricity production from renewable energy sources will increase by $5 \%$.

The positive forecasts for the renewable energy source (RES) sector contrasted with the negative dynamics of the energy sector as a whole are explained by three factors. First, at the moment renewable energy generation provides significant economic benefits compared to fossil fuels generation. In recent years, renewable energy has become much cheaper, and wind and sun are the cheapest energy sources in the world [Lazard, 2019]. Renewable energy sources also have low operating costs, and the low demand for electricity gives them an additional economic advantage. Second, in many countries, renewable energy power plants have priority access to the grid. Third, a large number of new renewable energy facilities have recently been commissioned, and many new RES power plants will be built by the end of 2020, despite the lockdown.

The digital economy is also one of the few sectors that, without any government support measures, has shown growth during the pandemic. This study shows that in most of the anti-crisis policy proposals digitalization itself is not proposed as an independent tool in the fight against the pandemic's consequences, but it is highly important in the restoration and greening of the economy, as noted in many documents. Thus, digitalization should be considered one of the original solutions to the unusual global economic crisis of 2020, not alone but together with climate solutions such as circular economy transition, low-carbon production and sustainable agriculture, and a transition to green energy. In other words, digitalization can increase the green sector's efficiency and reduce emissions, which in turn will contribute to the creation of new industries, companies and jobs and restore the economy in a completely different form. However, at the moment digitalization does not have the potential to become a key idea for anti-crisis policies.

At the same time, it is important to note that the green transformation of the economy and transition to sustainable development are long-term tasks, and their implementation may contradict some of the short-term anti-crisis policies. Therefore, especially during the first year of the crisis, it may be difficult for governments to focus on green industries given the need to manage the acute phase of the crisis and normalize economic life.

\section{Early Recovery Programmes for the World's Leading Economies}

The exact scope of post-pandemic global recovery programmes remains difficult to estimate. Different sources give quite different estimates, and the data are constantly updated. In June 2020, the IEA and the IMF estimated that the value of global anti-crisis programmes would be about $\$ 9$ trillion, while Bloomberg set this at about $\$ 12$ trillion; less than $0.2 \%$ of this sum was expected to be allocated between green sectors [Evans, Gabbatiss, 2020]. According to Vivid Economics estimates made at the end of July 2020, the size of global anti-crisis programmes reached \$11.8 trillion [Vivid Economics, 2020]. The report noted that 17 largest economies 
intended to spend about $\$ 3.5$ trillion to combat the consequences of the pandemic, and environmentally hazardous industries received more support than green sectors in 14 of them.

Data has been collected for early anti-crisis recovery programmes (as of August 2020) in 10 leading economies (Table 2). This data shows that by August 2020, most countries had only taken emergency post-crisis recovery measures, mainly in line with their usual anti-crisis policies. In particular, countries sought to support demand and provide short-term assistance to their populations, as well as to small and medium enterprises. Many of the largest polluters have weakened environmental standards, effectively allowing their factories to increase emissions. A similar situation was observed after the global crisis of 2008-09. At that time, the U.S. government first provided $\$ 700$ billion in support to the banking sector. Then, a few months later, a decision was made on an additional package of anti-crisis measures in the amount of $\$ 800$ billion, of which $\$ 80$ billion was spent on reducing greenhouse gas emissions, improving energy efficiency and technological innovation [Bloomberg, 2020]. This gives hope that the recommendations of the international community will be heard by governments and transformed into real actions, and the scale of support to the green sector this time will be more significant than after the crisis of $2008-09$.

Table 2. Anti-Crisis Programmes of the Top-10 Economies by GDP, August $2020^{2}$

\begin{tabular}{|c|c|c|}
\hline No. & Country & The Main Measures of Anti-Crisis Programmes \\
\hline 1 & $\begin{array}{l}\text { China } \\
\$ 592 \text { billion }\end{array}$ & $\begin{array}{l}\text { - Credit line extensions for state-owned enterprises; } \\
\text { - Infrastructure projects, including green ones; } \\
\cdot \text { Deregulation of environmental standards; } \\
\text { - Subsidies and tax breaks for environmentally harmful industries, as well as for } \\
\text { green projects; } \\
\text { - Environmental protection projects }\end{array}$ \\
\hline 2 & $\begin{array}{l}\text { U.S. } \\
\text { \$2.98 trillion }\end{array}$ & $\begin{array}{l}\text { - Payments to the population; } \\
\text { - Small and medium business support; } \\
\text { - Economic stabilization and assistance to the struggling sectors of the economy; } \\
\text { - Expanding credit availability; } \\
\text { - Assistance to airlines and strategically important enterprises; } \\
\text { - Deregulation of environmental standards; } \\
\text { - Subsidies for research and development in the green sector }\end{array}$ \\
\hline 3 & $\begin{array}{l}\text { India } \\
\text { \$266 billion }\end{array}$ & $\begin{array}{l}\cdot \text { Payments to the population; } \\
\text { - Small and medium business support; } \\
\text { - Infrastructure projects, including green ones; } \\
\text { - Deregulation of environmental standards; } \\
\text { - Subsidies and tax breaks for green product producers }\end{array}$ \\
\hline 4 & $\begin{array}{l}\text { Japan } \\
\$ 2.17 \text { trillion }\end{array}$ & $\begin{array}{l}\text { - Payments to the population; } \\
\text { - Support for large companies (airlines, car manufacturers); } \\
\text { - Small and medium business support; } \\
\text { - Green infrastructure projects }\end{array}$ \\
\hline 5 & $\begin{array}{l}\text { Germany } \\
\$ 1.38 \text { trillion }\end{array}$ & $\begin{array}{l}\text { - Payments to the population; } \\
\text { - Support for the most affected companies; } \\
\text { - Small and medium business support; } \\
\text { - Support for national exports; } \\
\text { - Expanding the credit availability; } \\
\text { - Green infrastructure projects; } \\
\text { - Subsidies for research and development in the green sector; } \\
\text { - Subsidies and tax breaks for green product manufacturers }\end{array}$ \\
\hline
\end{tabular}

\footnotetext{
${ }^{2}$ GDP, PPP (constant 2018 international \$).
} 


\begin{tabular}{|c|c|c|}
\hline 6 & $\begin{array}{l}\text { Russia } \\
\text { \$56 billion }\end{array}$ & $\begin{array}{l}\text { Payments to the population; } \\
\text { - Small and medium business support; } \\
\text { Support of environmentally hazardous industries }\end{array}$ \\
\hline 7 & $\begin{array}{l}\text { Brazil } \\
\text { \$221 billion }\end{array}$ & $\begin{array}{l}\text { - Support for the most vulnerable social groups, informal and self-employed } \\
\text { workers; } \\
\text { - Small and medium business support; } \\
\text { - Support for industry and transport } \\
\text { - Deregulation of environmental standards; } \\
\text { - Green infrastructure projects; } \\
\text { - Subsidies and tax breaks for green product manufacturers }\end{array}$ \\
\hline 8 & $\begin{array}{l}\text { Indonesia } \\
\text { \$46 billion }\end{array}$ & $\begin{array}{l}\text { - Support for the most vulnerable social groups; } \\
\text { - Small and medium business support; } \\
\text { - Deregulation of environmental standards; } \\
\text { - Green infrastructure projects; } \\
\text { - Green research and development subsidies; } \\
\text { - Subsidies and tax breaks for the green products manufacturers }\end{array}$ \\
\hline 9 & $\begin{array}{l}\text { UK } \\
\$ 630 \text { billion }\end{array}$ & $\begin{array}{l}\text { - Payments to the population; } \\
\text { - Support for the most affected companies; } \\
\text { - Deregulation of environmental standards; } \\
\text { - Green infrastructure projects; } \\
\text { - Green research and development subsidies; } \\
\text { Environmental protection projects. }\end{array}$ \\
\hline 10 & $\begin{array}{l}\text { France } \\
\$ 469 \text { billion }\end{array}$ & $\begin{array}{l}\text { - Support for the most affected companies; } \\
\text { - Transport sector support; } \\
\text { - Deregulation of environmental standards; } \\
\text { - Green infrastructure projects } \\
\text { - Green research and development subsidies; } \\
\text { - Subsidies and tax breaks for green product manufacturers }\end{array}$ \\
\hline
\end{tabular}

Source: Compiled by the authors based on Vivid Economics [2020] and other open sources.

So far, only the EU has demonstrated a real intention to significantly support the green sector in pursuing its anti-crisis policies. A quarter of the EU's anti-crisis spending, 850 billion euros in total, will go toward fighting climate change. In particular, measures will be taken to reduce dependence on fossil fuels, improve energy efficiency, preserve and restore natural capital and so on. In addition, all recovery loans and grants for EU members will contain the condition that environmental damage must be avoided.

Among the national anti-crisis plans, the German economic recovery plan totaling 130 billion euros is the most focused on green initiatives so far. The plan is for 2020-21. But even in this package only about 60 billion euros will be allocated to the green sector of the economy, which is less than half of the entire programme. These funds will be used to develop public transport, hydrogen energy, electric vehicles and renewable energy. The total announced spending on anti-crisis measures in Germany has already reached \$1.38 trillion (Table 2). Some measures aimed at green sector support will be taken in the UK and France, but these costs are much lower than in Germany. For example, in the UK they would comprise only \$445 million.

Korea may implement a programme similar to the European Green Deal. The country's leaders announced such plans after the victory of the Democratic Party in the elections to the National Assembly in April 2020. Korea's Green Deal could also include a goal of zero net emissions by 2050. Achieving this goal will make Korea the first carbon-neutral country in 
Asia. It is expected that in the near future this intention will have a significant impact on the anti-crisis policies of Korea.

According to Energy Policy Tracker, by early August 2020, G20 countries had committed more funds to support fossil fuel industries than to support clean energy as part of their anti-crisis programmes. An important exception is China, which will spend four times more on renewables than on fossil fuels. The United States will provide more benefits to traditional energy (Fig. 1). In total, the 20 largest economies in the world will allocate at least $\$ 169$ billion to support the energy sector, of which $47 \%$ is for fossil fuels and $39 \%$ for clean energy. Fostering the energy sector will be carried out through direct budgetary spending, tax breaks, soft loans, loan guarantees and so on.

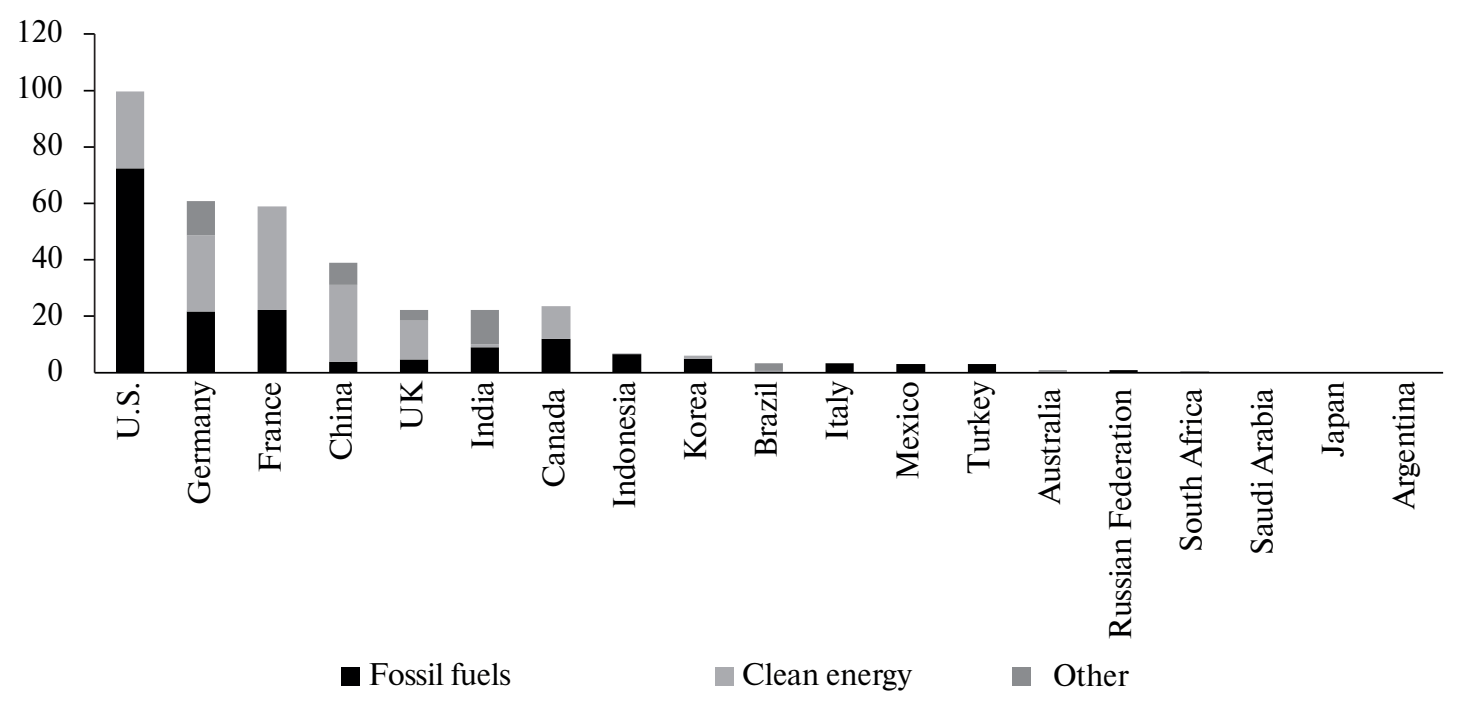

Fig. 1. The Energy Sector's Support in G20 Countries as a Part of Economic Recovery Programmes After the COVID-19 Pandemic, as of Early August 2020.

Source: [Energy Policy Tracker, 2020].

Thus, the real policies of the world's largest economies are not yet aimed at green recovery, nor at changing the economic paradigm. The measures taken and announced by governments in the first four months of the pandemic do not correspond to the principles of sustainable development and the goals of the Paris Agreement. They represent the business-as-usual paradigm. However, given the unprecedented consensus of the world community that the way out of the COVID-19 crisis should be green, there is hope that after the end of the acute phase of the crisis a second round of anti-crisis programmes will be aimed at a longer period and focused on the green sector of economy.

In the existing anti-crisis measures of the largest world economies digitalization is hardly mentioned separately, although it is already obvious that the digital sector of the economy has played a huge role in mitigating the economic crisis, creating opportunities for remote work and learning. It is also obvious that digitalization should be supported in emerging market countries in which underdeveloped digital infrastructure prevents the transfer of economic processes online, as was done in high-income countries. 


\section{Sustainable Development in a Pandemic: The Russian Context}

The terminology of sustainable development in general and the SDGs in particular has not yet been integrated into strategic documents in Russia. The sustainable development strategy in Russia has not been adopted. Even in the decree adopted in May 2018 [President of the Russian Federation, 2018], there were no references to the SDGs, although it is believed that this decree localized SDGs in Russia through the system of national projects. Thematically, many national projects directly or indirectly take into account some SDGs, but there is no direct mention of sustainable development goals. In addition, in the texts of national projects, there is not a word about sustainability as it is. The common terminology developed within the framework of the concept of sustainable development is not used, while Russia must use generally accepted concepts in order to act in line with its obligations.

For the implementation of national projects, special coordinating bodies were created, responsible ministers were appointed and the expected results of national projects were formulated in the form of quantitative goals - all this in general corresponds to world practices to implement the SDGs. At the same time, the connection of national projects with the SDGs is conditional; they are focused primarily on the implementation of goals and objectives of domestic policy, relevant even before the adoption of 2030 Agenda: education, health care and economic growth. The environmental aspect of the SDGs was not reflected in the national goals, and important aspects of the 2030 Agenda such as gender equality and human rights protection were not taken into account. In addition, national targets have been developed for the period up to 2024 .

In July 2020, due to the COVID-19 pandemic, the deadline for the implementation of national projects was postponed from 2024 to 2030. A new decree was also issued, and the adjusted national goals until 2030 were announced: preservation of the population, health and well-being of people; opportunities for self-realization and development of talent; comfortable and safe living environment; decent, efficient work and successful entrepreneurship; and digital transformation. These goals also overlap with the SDGs but are still not formally linked to them. Environmental aspects are taken into account within the framework of the national goal "comfortable and safe environment for life," which provides for the creation of a sustainable system for handling solid municipal waste, reducing emissions of hazardous pollutants, eliminating the most dangerous objects of accumulated environmental damage and ecological improvement of water bodies.

The actual implementation of the SDGs is not declared as a national priority; therefore, there is no body coordinating the implementation of the SDGs in the management system. Abroad, Russia is represented by the Ministry of Foreign Affairs and the Ministry of Economic Development of Russia. Partially, the Interdepartmental Working Group under the Presidential Administration of the Russian Federation on issues related to climate change partially implements the powers of the SDGs' coordinating body, but the 2030 Agenda is much broader than climate problems. In other countries, these coordination duties are performed directly by ministries within the executive branch or by prime ministers.

At the same time, as noted in the bulletin of the Accounting Chamber of the Russian Federation [2020], individual federal executive authorities acknowledge that their activities contribute to the implementation of the SDGs; however, unlike in foreign countries, their work on SDGs is proactive since Russia does not have a national strategy for the SDGs' implementation. No one is responsible for the comprehensive implementation of the SDGs in Russia.

To improve the efficiency of implementing the SDGs in Russia, it is necessary to: normatively consolidate the generally recognized understanding of sustainability abroad; institution- 
alize the concept of sustainable development at the state level by developing a national strategy for sustainable development and thus integrating the 2030 Agenda into strategic planning documents as well as by identifying a responsible agency; and organize efficient interagency cooperation. Russia has its own set of development priorities, but it should be more closely correlated with the sustainable development goals.

The COVID-19 pandemic has forced many governments to reconsider their priorities. For the first time in recent years, social goals (people's health and lives) were recognized as more important than economic ones: quarantines and self-isolation regimes were introduced and borders were closed despite the significant suspension of the service sector, tourism business, and the plight of small- and medium-sized enterprises. Under these conditions, the EU continued to work on the implementation of the European Green Deal approved at the end of 2019.

In Russia, green technologies and principles of sustainable development are not yet considered as a possible basis for post-crisis recovery. This state of affairs is a serious omission of the Russian economic policy, since as follows from the above analysis the world community has been calling on global leaders to support green industries from the very beginning of the pandemic, and this will most likely be implemented within the framework of the second wave of anti-crisis programmes. Russia runs the risk of being left out of this important trend, once again missing the opportunity to diversify its economy and lagging behind other countries in the development of new industries.

\section{Conclusion}

This article contains a content analysis of more than 20 proposals of international organizations, corporations, representatives of the academic sector and even government authorities regarding global, regional and national anti-crisis policies. The main demand of the international community, which is clearly expressed in almost all the proposals reviewed, is the demand to carry out economic recovery after the pandemic by solving the climate and environmental crises and supporting green industries. Many proposals also note the exceptional role of the digital sector of the economy, as it allowed the world to minimize the negative economic consequences of the pandemic in the short term through the partial or complete transition of most processes online in corporations, universities and schools. They also emphasize the importance of inclusiveness and fairness while overcoming the crisis and the need to place individuals and communities, not corporations, at the centre of recovery policies.

These proposals do not directly correspond to the anti-crisis measures taken before August 2020. Support measures already implemented or announced by the governments of the world's largest economies included some incentives to develop green infrastructure, renewable energy and energy efficiency. However, their scale is very small compared to the traditional anti-crisis measures, which include demand support, first aid assistance to the most affected industries, often imposing extremely negative impact on the environment, large corporations, and so on. Thus, the real anti-crisis economic policy is still far from the international community's requirements. Governments take measures aimed at preserving the trends that were observed before the pandemic - in particular, stimulating the traditional energy sector. Moreover, many major polluters have relaxed environmental requirements. This will slow the recovery and exacerbate environmental and climate problems. Digitalization is also largely unmentioned in the anti-crisis programmes.

Based on this analysis, support for the following in national anti-crisis programmes is recommended: 
- Clean energy and transport electrification;

- Circular economy and reducing the negative impact of industrial enterprises on the environment;

- Accelerated digitalization and partial transition to the online mode on an ongoing basis in those organizations that do not require the daily presence of employees at their workplaces;

- Protection and restoration of natural ecosystems.

Since many countries have managed to take only emergency anti-crisis measures so far, there is a chance that during the second wave, governments will have more opportunities to assess the long-term consequences of the crisis, and these recommendations will be fully or at least partially taken into account.

These recommendations are also relevant for Russia. On the whole, Russia's domestic policies are not yet focused on sustainable development. In Russia, no work has been carried out to localize the SDGs, a system for their implementation has not been formed, and only certain areas of internal socio-economic policies overlap with particular sustainable development goals. Russian anti-crisis packages do not include measures to support green sectors. At the same time, given the depth of the crisis and the obvious focus of the world community on a green economic recovery, Russia needs to pay attention to green industries and the circular economy. Otherwise, there is a risk of Russia's being more and more left behind.

\section{References}

350. (2020) Open Letter: Principles for a \#JustRecovery From COVID-19. Available at: https://350.org/just-recovery/ (accessed 1 November 2020).

Accounting Chamber of the Russian Federation. (2020) Otchet o rezul'tatakh ekspertnoanaliticheskogo meropriyatiya "Analiz sistemy gosudarstvennogo upravleniya po vnedreniyu povestki ustoychivogo razvitiya za period 2019 goda, istekshiy period 2020 goda" [Report on the Results of the Expert-Analytical Event "Analysis of the Public Administration System for the Implementation of the Sustainable Development Agenda for the Period of 2019, Expired 2020"]. Available at: https://ach.gov.ru/upload/iblock/761/76119231ce487594c1301b38be450c96.pdf (accessed 9 August 2020) (in Russian).

Autengruber C. (2020) Open Letter to EU Leaders From the President of the European Youth Forum, 19 June. Available at: https://www.youthforum.org/open-letter-eu-leaders (accessed 2 November 2020).

Bailey A., Carney M., Villeroy de Galhau F., Elderson F. (2020) The World Must Seize This Opportunity to Meet the Climate Challenge. The Guardian, 5 June. Available at: https://www.theguardian.com/commentisfree/2020/jun/05/world-climate-breakdown-pandemic (accessed 1 November 2020).

Bickler G., Morton S., Menne B. (2020) Health and Sustainable Development: An Analysis of 20 European Voluntary National Reviews. Public Health, vol. 180, pp. 180-4. Available at: https://doi.org/10.1016/j. puhe.2019.10.020 (accessed 30 July 2020).

Biggeri M., Clark D.A., Ferrannini A., Mauro V. (2019) Tracking the SDGs in an 'Integrated' Manner: A Proposal for a New Index to Capture Synergies and Trade-Offs Between and Within Goals. World Development, vol. 122, pp. 628-47. Available at: https://doi.org/10.1016/j.worlddev.2019.05.022 (accessed 30 July 2020).

Birol F. (2020) Put Clean Energy at the Heart of Stimulus Plans to Counter the Coronavirus Crisis. International Energy Agency Commentary, 14 March. Available at: https://www.iea.org/commentaries/put-clean-energyat-the-heart-of-stimulus-plans-to-counter-the-coronavirus-crisis?fbclid=IwAR2OLte-zKQR0tB178QGtpu5tzhCZhe6R3sA64W9uF4JgDtUVyj1bJj8T7c (accessed 1 November 2020).

Bloomberg. (2020) How to Grow Green. Available at: https://www.bloomberg.com/features/2020-green-stimulus-clean-energy-future/?sref=Oz9Q3OZU\#toaster (accessed 9 August 2020).

Bobylev S.N., Solovyova S.V. (2017) Tseli ustoychivogo razvitiya dlya budushchego Rossii [Sustainable Development Goals for the Future of Russia]. Problemy prognozirovaniya [Problems of Forecasting], no 3. Available 
at: https://cyberleninka.ru/article/n/tseli-ustoychivogo-razvitiya-dlya-buduschego-rossii (accessed $30 \mathrm{July}$ 2020) (in Russian).

C40 Cities. (2020) "No Return to Business as Usual": Mayors Pledge on COVID-19 Economic Recovery. Press Release, 7 May. Available at: https://www.c40.org/press_releases/taskforce-principles (accessed 1 November 2020).

Club of Rome. (2020) An Open Letter to Global Leaders: A Healthy Planet for Healthy People. 26 March. Available at: https://clubofrome.org/impact-hubs/climate-emergency/open-letter-to-global-leaders-a-healthyplanet-for-healthy-people/?fbclid=IwAR0US_KfNnxKMeWCSN3Er1cZwneRPzA4kqwvgEvEUPeglEuoumrs2cNQmHs (accessed 1 November 2020).

Dunayev O.I., Nagornov V.A. (2017) Garmonizatsiya praktiki korporativnoy sotsial'noy otvetstvennosti dlya dostizheniya tseley ustoychivogo razvitiya [Harmonization of Corporate Social Responsibility Practices to Achieve Sustainable Development Goals]. Gosudarstvenno-chastnoye partnerstvo [Public-Private Partnership], no 2. Available at: https://cyberleninka.ru/article/n/garmonizatsiya-praktiki-korporativnoy-sotsialnoy-otvetstvennosti-dlya-dostizheniya-tseley-ustoychivogo-razvitiya (accessed 30 July 2020) (in Russian).

ElMassah S., Mohieldin M. (2020) Digital Transformation and Localizing the Sustainable Development Goals (SDGs). Ecological Economics, vol. 169. Available at: https://doi.org/10.1016/j.ecolecon.2019.106490 (accessed 30 July 2020).

Energy Policy Tracker. (2020) Track Public Money for Energy in Recovery Packages. Available at: https://www. energypolicytracker.org/ (accessed 8 August 2020).

European Alliance to Save Energy. (2020) Open Letter to EU Leaders: Delivering the European Green Deal for a Sustainable and Efficient Recovery of Our Economy, 6 April. Available at: https://euase.net/letter-eu-leadersdelivering-green-deal-sustainable-efficient-recovery/ (accessed 1 November 2020).

European Climate and Environment Ministers. (2020) European Green Deal Must Be Central to a Resilient Recovery After Covid-19. Climate Home News, 9 April. Available at: https://www.climatechangenews. com/2020/04/09/european-green-deal-must-central-resilient-recovery-covid-19/?fbclid=IwAR0RIkI43zK9 yBQJjnPyQuMwJ6wQLCDbXZAqGkTGg7qRG9FpXg06xMjIDqU (accessed 1 November 2020).

Evans S., Gabbatiss J. (2020) Coronavirus: Tracking How the World's 'Green Recovery' Plans Aim to Cut Emissions. Carbon Brief, 16 June. Available at: https://www.carbonbrief.org/coronavirus-tracking-how-the-worldsgreen-recovery-plans-aim-to-cut-emissions (accessed 8 August 2020).

Hepburn C., O'Callaghan B., Stern N., Stiglitz J., Zenghelis D. (2020) Will COVID-19 Fiscal Recovery Packages Accelerate or Retard Progress on Climate Change? Oxford Review of Economic Policy, vol. 36, no S1, pp. S359-81. Available at: https://doi.org/10.1093/oxrep/graa015 (accessed 8 August 2020).

Ignatov A.A., Mikhnevich S.V., Popova I.M., Safonkina Ye.A., Sakharov A.G., Shelepov A.V. (2018) Podkhody vedushchikh stran-donorov k vnedreniyu TSUR v natsional'nyye strategii ustoychivogo razvitiya [Approaches of the Leading Donor Countries to the Implementation of the SDGs in National Strategies for Sustainable Development]. Vestnik mezhdunarodnykh organizatsiy [International Organisations Research Journal], vol. 14, no 1, pp. 164-88. Available at: https://iorj.hse.ru/2019-14-1/252925992.html (accessed 30 July 2020) (in Russian).

International Energy Agency (IEA). (2020a) Report: The Covid-19 Crisis and Clean Energy Progress. Available at: https://www.iea.org/reports/the-covid-19-crisis-and-clean-energy-progress/power\#abstract (accessed 30 July 2020).

International Energy Agency (IEA). (2020b) Sustainable Recovery: World Energy Outlook Special Report. Available at: https://www.iea.org/reports/sustainable-recovery/covid-19-and-energy-setting-the-scene\#abstract (accessed 1 November 2020).

International Labour Organization (ILO). (2020) COVID-19 and the World of Work. Fifth Edition. ILO Monitor, 30 June. Available at: https://www.ilo.org/wcmsp5/groups/public/@dgreports/@dcomm/documents/ briefingnote/wcms_749399.pdf (accessed 31 July 2020).

International Monetary Fund (IMF). (2018) Measuring the Digital Economy. IMF Policy Paper. Available at: https://www.imf.org/en/Publications/Policy-Papers/Issues/2018/04/03/022818-measuring-the-digitaleconomy $\#: \sim:$ text $=$ The $\% 20$ digital $\% 20$ sector $\% 20$ covers $\% 20$ the, such $\% 20$ as $\% 20$ the $\% 20$ sharing $\% 20$ economy (accessed 31 July 2020). 
International Monetary Fund (IMF). (2020) A Crisis Like No Other, An Uncertain Recovery. World Economic Outlook Update. Available at: https://www.imf.org/en/Publications/WEO/Issues/2020/06/24/WEOUpdateJune2020 (accessed 30 July 2020).

International Renewable Energy Agency (IRENA). (2020) Post-COVID Recovery: An Agenda for Resilience, Development and Equality. Available at: https://www.irena.org/publications/2020/Jun/Post-COVID-Recovery (accessed 31 July 2020).

Janowski T. (2016) Implementing Sustainable Development Goals With Digital Government - AspirationCapacity Gap. Government Information Quarterly, vol. 33, no 4, pp. 603-13. Available at: http://dx.doi. org/10.1016/j.giq.2016.12.001 (accessed 30 July 2020).

Lanshina T.A., Barinova V.A., Loginova A.D., Lavrovskiy Ye. P., Ponedelnik I.V. (2019) Opyt lokalizatsii i vnedreniya Tseley ustoychivogo razvitiya v stranakh - liderakh v dannoy sfere [Localizing and Achieving the Sustainable Development Goals at the National Level: Cases of Leadership]. Vestnik mezhdunarodnykh organizatsiy [International Organisations Research Journal], vol. 14, no 1, pp. 207-24. Available at: https://iorj.hse. $\mathrm{ru} / 2019-14-1 / 252926210 . h t m l$ (accessed 30 July 2020) (in Russian).

Lawler A. (2020) End Game for Oil? OPEC Prepares for an Age of Dwindling Demand. Reuters, 28 July. Available at: https://www.reuters.com/article/us-global-oil-demand-insight/end-game-for-oil-opec-prepares-foran-age-of-dwindling-demand-idUSKCN24T0KT (accessed 30 July 2020).

Lazard. (2019) Lazard's Levelized Cost of Energy Analysis - Version 13.0. Available at: https://www.lazard.com/ media/451086/lazards-levelized-cost-of-energy-version-130-vf.pdf (accessed 31 July 2020).

Le Blanc D. (2015) Towards Integration at Last? The Sustainable Development Goals as a Network of Targets. Sustainable Development, vol. 23, no 3, pp. 176-87. Available at: https://doi.org/10.1002/sd.1582 (accessed 30 July 2020).

Millionaires for Humanity. (2020) 'Millionaires for Humanity' Sign On Letter. Available at: https://www.millionairesforhumanity.com (accessed 1 November 2020).

President of the Russian Federation (2018) Ukaz: O natsional'nykh tselyakh i strategicheskikh zadachakh razvitiya Rossiyskoy Federatsii na period do 2024 goda [Decree: On National Goals and Strategic Objectives of the Development of the Russian Federation for the Period up to 2024]. Available at: http://www.kremlin.ru/acts/ bank/43027 (accessed 5 August 2020) (in Russian).

Ramos M. (2020) COVID-19 Could Widen the Digital Gap. Here's What's Needed Now. World Economic Forum, 30 July. Available at: https://www.weforum.org/agenda/2020/07/covid-19-could-widen-the-digitalgap-here-is-what-is-needed-now/ (accessed 30 July 2020).

Sakharov A.G., Kolmar O.I. (2019) Perspektivy realizatsii Tseley ustoychivogo razvitiya OON v Rossii [Prospects for the Implementation of the UN Sustainable Development Goals in Russia]. Vestnik mezhdunarodnykh organizatsiy [International Organisations Research Journal], vol. 14, no 1, pp. 189-206. Available at: https:// iorj.hse.ru/2019-14-1/252926099.html (accessed 30 July 2020) (in Russian).

Sebestyén V., Domokos E., Abonyi J. (2020) Focal Points for Sustainable Development Strategies: Text Mining-Based Comparative Analysis of Voluntary National Reviews. Journal of Environmental Management, vol. 263. Available at: https://doi.org/10.1016/j.jenvman.2020.110414 (accessed 30 July 2020).

Stay Grounded Network. (2020) No Unconditional Airline Bailouts: Taking Care of People, Not Airlines. Letter from Magdalena Heuwiser, 18 March, Stay Grounded Network. Available at: https://stay-grounded. org/wp-content/uploads/2020/03/Open_Letter_EU_Transport_Ministers.pdf (accessed 1 November 2020).

United Nations (UN). (2020) Shared Responsibility, Global Solidarity: Responding to the Socio-Economic Impacts of COVID-19. Available at: https://www.un.org/sites/un2.un.org/files/sg_report_socio-economic_impact_ of_covid19.pdf?fbclid=IwAR2miQC91EfmCd7bpnPowby59JpRTASLzIwp1QN-LJEC6nsjt6HgruCXGoQ (accessed 1 November 2020).

United Nations Environment Programme (UNEP). (2011) Towards a Green Economy: Pathways to Sustainable Development and Poverty Eradication: A Synthesis for Policy Makers. Available at: https://sustainabledevelopment.un.org/content/documents/126GER_synthesis_en.pdf (accessed 1 November 2020).

Various Canadian Environmental Organizations. (2020) Nature Conservation Should Be Central to Canada's Recovery From Covid-19. Letter to Prime Minister Trudeau, 10 July. Available at: https://cpaws.org/wp-con- 
tent/uploads/2020/07/Nature-Conservation-Letter-to-PM-July-10-2020-EN-3.pdf (accessed 2 November 2020).

Various Civil Aviation Organizations. (2020) EU COVID-19 Green Recovery Funding for the Decarbonisation of Civil Aviation. Open Letter to EU Ministers and European Commissioners, 24 June. Available at: https:// www.iata.org/contentassets/9476502c15c1487b82634619695e7f6e/civil-aviation-green-recovery-proposals. pdf (accessed 2 November 2020).

Various Corporate Leaders. (2020) Letter to Rt Hon Boris Johnson, 1 June. Available at: https://www.corporateleadersgroup.com/reports-evidence-and-insights/pdfs/final-290520-business-groups-ceo-resilient.pdf (accessed 1 November 2020).

Various Health Professionals. (2020) In Support of a \#HealthyRecovery. Letter to Group of 20 Leaders, 26 May. Available at: https://healthyrecovery.net (accessed 1 November 2020).

Various Investors. (2020) Open Letter to EU Leaders From Investors on a Sustainable Recovery From COVID-19. Available at: https://theinvestoragenda.org/wp-content/uploads/2020/06/Open-letter-to-EU-leaders-frominvestors-on-a-sustainable-recovery-from-COVID-19.pdf (accessed 1 November 2020).

Various Signatories. (2020) Green Recovery: Reboot \& Reboost Our Economies for a Sustainable Future: Call for Mobilisation. Available at: https://euase.net/wp-content/uploads/2020/04/Green-Recovery-Call-to-ActionSignatories.pdf (accessed 1 November 2020).

Various U.S. Corporations. (2020) Letter to Majority Leader McConnell, Speaker Pelosi, Leader Schumer, and Leader McCarthy, 21 July. Available at: https://www.mcdonalds.com/content/dam/gwscorp/nfl/homepage/ COVID_Packages_Renewable_Business_Letter_Final_07_21_20.pdf (accessed 2 November 2020).

Vivid Economics. (2020) Green Stimulus Index. Available at: https://www.vivideconomics.com/wp-content/ uploads/2020/04/200723-GreenStimulusIndex_web.pdf (accessed 8 August 2020).

World Bank (2020) Pandemic, Recession: The Global Economy in Crisis. Available at: https://www.worldbank.org/en/publication/global-economic-prospects (accessed 30 July 2020).

World Health Organization. (2020) WHO Manifesto for a Healthy Recovery From COVID-19. 26 May. Available at: https://www.who.int/news-room/feature-stories/detail/who-manifesto-for-a-healthy-recovery-from-covid-19 (accessed 1 November 2020).

Zhou X., Moinuddin M. (2017) Sustainable Development Goals Interlinkages and Network Analysis: A Practical Tool for SDG Integration and Policy Coherence. IGES Research Report, Institute for Global Economic Strategies. Available at: https://www.iges.or.jp/en/pub/sustainable-development-goals-interlinkages/en (accessed 1 November 2020). 